\title{
Montaigne's Vanity: Reading Digressions on Travel
}

VIRGINIA M. GREEN

Summary: The theme of travel, prominent in the essay "De la Vanite" (III, 9), and the subject of many of its "digressions," serves, in a sense, to disguise the more central and unifying theme of vanity. The question of vanity lies behind all of Montaigne's so-called "digressions" on travel, which are not really digressions from his stated theme at all, but rather ways of recasting and examining vanity in a more personal vein. Travel is perhaps the essayist's chief vanity; yet, despite its inherent vanity, Montaigne takes great pleasure in this self-indulgence.

$F$ or centuries, much has been said about the "disorder" of Montaigne's Essais, ${ }^{1}$ and specifically more pertinent here, about the digressive nature of the essay. "De la Vanite," the longest from the third book. ${ }^{2}$ Montaigne's elaborate discussions of travel are by far the most substantial "digressions" of the essay, and it is this prominence of the travel theme that led Grace Norton to hypothesize the piecing together of two separate essays on vanity and travel. ${ }^{3}$ However, the different thematic and philological threads that run throughout "De la Vanite" are far too tightly interwoven to have been pieced together in a patchwork fashion.

Montaigne himself was fully aware of the seemingly digressive nature of his writing, as many of his readers know. His remarks in "De la Vanite" both note his discursive writing style and at the same time stress the underlying unity of the essay: "Je m'esgare, mais plustot par licence que par mesgarde. Mes fantasies se suyvent, mais par fois c'est de loing, et se regardent, mais d'une veuë oblique" (994B). "De la Vanité," some might say, is a case in point, for 
what do such apparently diverse topics as household affairs, old age and death, discussions of Paris and Rome, the civil strife in France, writing, and travel all have to do with vanity? Yet, this precisely is the point, for as Montaigne suggests, the connection, while perhaps not obvious, is nonetheless there.

The well-known phrase from Ecclesiastes ("vanitas vanitatum, et omnia vanitas"), alluded to in the first lines of the essay, echoes throughout. In a sense the essay is Montaigne's personal dialogue with the dictum "all is vanity," and the richness and inherent unity of this essay are more fully appreciated with a thorough understanding of just how solidly Montaigne has anchored his "digressions" to his theme.

Montaigne's remarks and discussions of travel both admit and deny that travel is vanity. The essayist looks at travel from many different angles, finding both advantages and disadvantages in this activity. The prominence of the travel theme serves to disguise the more central and unifying theme of vanity. Montaigne's digressions on travel are not digressions at all, but are in fact examples, or illustrations of his theme, or ways of recasting and examining the question of vanity in a more personal vein. Travel is perhaps Montaigne's chief vanity; it is closely associated with, and is the ultimate result of, Montaigne's other vanities which provide the subjects for many other "digressions" of this essay. For Montaigne, discussing travel is another way of examining vanity, and of questioning its meaning and relevance in his own life.

The relationship between travel and writing is both fundamental and of paramount importance for Montaigne in "De la Vanité." Throughout the essay the themes of travel and writing are constantly and consistently interchangeable. Travel is often a metaphor for writing, and writing is a frequent metaphor for travel. Distinctions become blurred; is Montaigne discussing travel, or writing, or both? When Montaigne's subject is the physical voyage it can usually be inferred that he is at the same time referring to the voyage of the pen, to the writing of essays.

The coupling of these two subjects occurs from the very beginning of the essay, as Montaigne introduces the travel image in the third sentence, commenting both on his current undertaking of writing about vanity and on writing the Essais in general: "Qui ne voit que j'ay pris une route par laquelle, sans cesse et sans travail, j'iray autant qu'il y aura d'ancre et de papier au monde" (945B)? Here travel is a metaphor for writing and the voyage Montaigne is describing is the voyage of the pen: an infinite, never-ending voyage, or a creative process that will never succeed in completely filling the empty pages, the void that stretches before it. ${ }^{4}$ In this sense, then, Montaigne's project is one 
of vanity: he could write forever without the infinite plenitude of his writing ever completely filling the even more infinite emptiness of the space he is writing in. Montaigne's literary voyage is an inherently vain one.

The reasons given by Montaigne for his travels are many: for personal pleasure, to gain knowledge, to avoid the upheaval of France's civil wars, to avoid both public and private obligations of his household, and in the hope that he will be able to die his own private death away from family and friends. Montaigne acknowledges or suggests the vanity of each of these motivations, yet he does not allow the admitted vanity of his reasons for travel to deter him from his chosen course of action. Like Erasmus in his Praise of Folly, Montaigne writes his essay in praise of vanity, finding and celebrating the positive in what traditionally has been seen as a sin or vice to be avoided. Montaigne's reasons for travel may be vanity, and travel may also be vanity, but that does not stop him from traveling or from taking pleasure in his voyages.

Montaigne's voyages are far more than just physical voyages. When discussing his travels, Montaigne is ostensibly referring to sojourns in Paris and Rome, among others; however, the essayist's voyages can also be of the literary or intellectual variety. In addition to being a seasoned traveler, Montaigne is also an "armchair traveler" as well as a "time traveler," voyaging via books to the colonies and newly discovered civilizations of the New World, or to visit the cities and personages of antiquity. Montaigne's voyages are also intellectual voyages of the pen as he tests or "essays" himself against the authors of antiquity (as in the first two books) and later, in the third book, against himself. Whether Montaigne undertakes a real voyage to Rome or just escapes to the solitude of his library to read, reflect, and write, the effect is the same: he finds enjoyment and knowledge, and he escapes the turmoil of the civil wars as well as his personal and domestic obligations.

Pleasure is the initial reason Montaigne acknowledges as one of his main motivations for his travels: "Parmy les conditions humaines, cette-cy est assez commune: de nous plaire plus des choses estrangeres que des nostres et d'aymer le remuement et le changement" (948B, my emphasis). Montaigne's pleasure takes many different forms and all are linked to vanity: his pleasure in discovering new and different things, his pleasure in learning, and the sheer satisfaction he experiences from the physical movement of travel.

Montaigne's enjoyment of travel and his pleasure in experiencing newness, difference, variety and diversity are strongly tied to vanity. Montaigne is excited by the new and unknown, and he cites his "humeur avide des choses 
nouvelles et inconnues" (948B, my emphasis) as one of the principal reasons for his travels. These two adjectives, "new" and "unknown," are repeated when Montaigne declares one of the benefits of travel to be that "L'ame y a une continuelle exercitation à remarquer les choses incogneuës et nouvelles" (973B, my emphasis). The words "unknown" and "new" imply vanity in two ways. First, if knowledge indeed is vanity (a reference here to the topos of the vanity of knowledge), then seeking the unknown is vanity. Secondly, Ecclesiastes declares that seeking the new is vanity because "there is nothing new under the sun." The biblical passage continues, "Is there a thing of which it is said, 'See, this is new'? It has been already, in the ages before us" (1:910). Thus the topos of the vanity of knowledge and the intertext of Ecclesiastes suggest that Montaigne's desire to search out both the unknown as well as the new is vanity.

The recognition of travel's educational benefits appears to be in direct opposition to the topos of the vanity of knowledge. However, Montaigne subtly shows the revers de la médaille when he states that travel is a good school because "Le corps n'y est ny oisif ny travaillé, et cette moderée agitation le met en haleine" (974B, my emphasis). The word "haleine" is doubly significant. Associated with wind and the breath of life and inspiration, ${ }^{5}$ "haleine" also strongly suggests vanity as it is one of the possible translations of the Hebrew word ruach, from the expression "striving after wind," found in Ecclesiastes. Thus, while praising the knowledge to be gained from travel, Montaigne at the same time acknowledges the topos of the vanity of knowledge, suggesting with the word "haleine" that to travel to gain knowledge may also be an empty endeavor, that is, his desire for self-improvement through travel may also be vanity.

Montaigne's avowed enjoyment of travel is, therefore, twofold. To do something for personal pleasure is self-indulgent, the epitome of vanity, and at the same time, as Eccleasiastes teaches, ${ }^{6}$ enjoyment is a sort of antidote, or man's only recourse to the vanities of the world. In emphasizing the pleasure he derives from travel ${ }^{7}$ Montaigne is both recognizing and admitting his own vanity as well as following the lesson of Ecclesiastes, as if to say, "If all is vanity, then I might as well enjoy myself."

Montaigne's description of how he likes to travel (p. 974 of the Villey edition) is itself a self-fulfilling act of vanity, in the sense of boasting, ostentation, or self-conceit. Beginning with, "Je me tien à cheval sans demonter, tout choliqueux que je suis ..." (974B), almost every sentence in this passage begins with the pronoun $J e^{8}$, or is otherwise personalized with some first 
person pronoun or adjective, almost as if in defiance of the classical rhetorical convention of not talking about oneself. ${ }^{9}$ Montaigne's focus on the self in this passage, his concentrated use of the first person, is a conscious exercise in vanity. This cataloguing of his likes and dislikes while traveling foreshadows a similar focus on personal habits enumerated in "De l'Experience" (III, 13), which some critics have found vain and superfluous.

Montaigne's discussion and descriptions of the pleasure he obtains from new and different experiences and his pleasure in learning directly counter the commonplace notion that knowledge is vanity. Yet, while Montaigne asserts the benefits of traveling to gain knowledge, he also points out the vanity of not taking advantage of opportunities afforded by travel to gain knowledge. Montaigne also sees vanity in being close-minded vis-à-vis new experiences. In criticizing the attitude of national superiority of some of his compatriots and their refusal to try new things Montaigne implies that such an attitude is a manifestation of vanity:

J'ay honte de voir noz hommes enyvrez de cette sotte humeur de s'effaroucher des formes contraires aux leurs: il leur semble estre hors de leur element quand ils sont hors de leur vilage. Où qu'ils aillent, ils se tiennent à leurs façons, et abominent les estrangeres (985B, my emphasis).

The word "enyvrez" suggests the excess to which these people have taken their feelings of national pride, while "sotte" implies the emptiness and vanity of this attitude. Thus, full of feelings of their own superiority ("cette sotte humeur"), they are unable to appreciate anything different, and instead denigrate and refuse to try any and all foreign customs. They are limiting themselves to the paucity of the known and the familar while denying themselves the richness and diversity present in unknown and different cultures, and they are the poorer for it. ${ }^{10}$

The voyage as a vehicle for learning, and gaining knowledge is useless if one does not have an open mind: "Ils voyagent couverts et resserrez d'une prudence taciturne et incommunicable, se defendans de la contagion d'un air incogneu" (986B). The phrase "couverts et resserrez" emphasizes how impervious and impenetrable these people are to new ideas and customs. Full of, as well as protecting and armoring themselves with an excessive prudence, they will not profit at all from their voyage - they will return as though empty, having absorbed nothing new from their travels. This refusal of new experiences is vanity because one gains nothing, and it is likewise vain (that is, useless or futile) to travel if one is not open to learning from one's voyage. 
Montaigne reinforces the vanity of close-mindedness with the example of certain young courtiers who

ne tiennent qu'aux hommes de leur sorte, nous regardent comme gens de l'autre monde, avec desdain ou pitié. Ostez leur les entretiens des mystères de la court, ils sont hors de leur gibier, aussi neufs pour nous et malhabiles comme nous sommes à eux (986B).

These young courtiers are so full of themselves, and their knowledge is so limited, that out of their environment they are like fish out of water, and since they completely lack knowledge of anything except court affairs they are unable to function in different situations. Montaigne underscores the vanity of these young men in concluding, "On dict bien vray qu' un honneste homme c'est un homme meslê" (986B, my emphasis). Vray from veritas also implies its opposite, vanitas. Un "homme meslé" is a man of many interests and talents, and can therefore function in a variety of settings and situations. On the contrary, men such as these young courtiers are full only of themselves and are therefore paradoxically empty out of their own milieu. Likewise, travelers consumed with their own national pride or superiority are impervious to their surroundings and new experiences, and return from their travels both literally and metaphorically empty-handed, having gained nothing.

Montaigne presents himself, of course, as the complete antithesis of these two examples. He is not subject to excessive national pride or arrogance, ${ }^{11}$ and he takes advantage of every possible new experience he encounters while traveling, actively seeking out the new and different. ${ }^{12}$ Montaigne's own selfportrait reveals him as an exemplary "homme meslé" and an epitome of openmindedness. ${ }^{13}$ Travel may be vanity and Montaigne's traveling for his own enjoyment may be the ultimate vanity, but at least Montaigne is not guilty of the vanity of not benefiting and learning from his voyages.

Montaigne examines at some length the self-indulgence and vanity of his preference for travel over staying at home by posing himself a series of questions, as though imagining the queries of family and friends unable to comprehend his continual desire to absent himself from a situation they find enviable. "Avez-vous pas des passe-temps plus aysez? Dequoy avez-vous faute? Votre maison est elle pas en bel air et sain, suffisamment fournie, et capable plus que suffisamment?" (987B). Why, when seemingly he has all that he should need or want, does Montaigne desire to leave, to travel, to be elsewhere $:{ }^{14} \mathrm{He}$ realizes that this discontent stems not from deficiencies in his circumstances but rather from within himself: 
Où cuidez vous pouvoir estre sans empeschement et sans destourbier? [. . .] Voyez donc qu'il n'y a que vous qui vous empeschez, et vous vous suyverez par tout, et vous plaindrez par tout. Car il n'y a satisfaction çà bas que pour les ames ou brutales ou divines. Qui n'a du contentement à une si juste occasion, où pense il le trouver (987B)?

Problems and dissatisfactions, Montaigne recognizes, are part of the human condition, and trying to escape or find perfect contentment is an exercise both in futility and vanity because difficulties and discontentments will always arise. Contentment is to be found from within, not from without, and it is therefore vanity to seek from without the fulfillment which can only be found within oneself. Montaigne's acknowledgement of his discontent and of its source within himself echoes the warnings of Ecclesiastes: "All the toil of man is for his mouth, yet his appetite is not satisfied [. . . ]. Better is the sight of the eyes than the wandering of desire; this also is vanity and a striving after wind" $(6: 7,9) .^{15}$

Concluding his self-examination of the vanity of his desire to travel, Montaigne gives himself the following advice: "Reformez vous seulement, car en cela vous pouvez tout, là où vous n'avez droict que de patience envers la fortune" (987B). In self-reform man is capable of tout, whereas it is implied that in everything else man's efforts will at best yield only partial results and at worst yield nothing or emptiness. Tout alludes to its opposite rien, and suggests that man's efforts to accomplish anything outside himself are vanity, since man has complete power only over himself.

Having thus examined the vanity of his desire to travel, Montaigne progresses to suggest subtly that his enjoyment of travel is also vanity: "ce plaisir de voyager porte tesmoignage d'inquietude et d'irresolution" (986B, my emphasis). The Villey edition of the Essais gives the modern equivalent for "d'inquietude et d'irresolution" as "d'agitation et d'inconstance," which suggests the familiar inconsistency of the wind commonly associated with vanity. A few lines later, reiterating the title of his essay, Montaigne declares openly and unequivocally through an imaginary interlocutor that travel is vanity:

Une seule corde ne m'arreste jamais assis. - Il y a de la vanité dictes vous, en cet amusement. - Mais où non? Et ces beaux preceptes sont vanité, et vanité toute la sagesse. [C] Dominus novit cogitationes sapientium, quoniam vanae sunt (988B, my emphasis).

The expression "cet amusement" ostensibly refers to travel, but also to the very act of writing in which Montaigne is engaged. Montaigne's reiteration of the 
essay title makes the reader sit up and take notice of this statement. The vanity of travel (and/or the vanity of writing) is emphasized by the repetition of the word "vanite", which appears three times in these two sentences, in addition to the inclusion of the adjectival form "vanae" in the allongeail taken from the Bible. There are only eight occurences of "vanité" in this essay (including the title), and three of these are found in these two sentences. The reiteration of the title, coupled with the redundancy of the word "vanité," makes this a focal passage of the essay where the duality and simultaneity of travel and writing are clearly apparent.

Paradoxically, however, the strong emphasis on the word "vanite" in this passage has also exactly the opposite effect, calling into question the very vanity Montaigne is supposedly asserting. Montaigne's favorite pastime, travel (and/or writing) is declared vain, but the stigma of vanity is reduced with Montaigne's observation that vanity is everywhere, even in "ces beaux preceptes" and "toute la sagesse." If concepts with such positive connotations as "beaux preceptes" and wisdom are vanity, then the vanity of Montaigne's travel/writing and his enjoyment of it loses its many negative connotations. Thus by stressing the ubiquitousness of vanity, Montaigne makes the vanity of his enjoyment of travel/writing seem a relatively minor fault.

Montaigne acknowledges, admits to, and even flaunts, the vanity of his travels and the pleasure he derives from this activity. And he blithely continues the vain self-indulgence of both his physical and literary voyages, unrepentant.

\section{Phillips University}

\section{Notes}

1. Critics have long been struck by the disorder and digressions of the Essais in general, and of "De la Vanite" in particular. I am thinking specifically of comments made by Guez de Balzac, Charles Sorel, Pascal (see Appendix II in the Villey and Saulnier edition) and of Villey himself: "l'on trouve ici [in III,9] l'un des exemples les plus frappants de ce désordre au moyen duquel Montaigne aime à étonner et à dérouter son lecteur" (944, my emphasis).

2. All quotations from the Essais are from the edition by Pierre Villey and Verdun L. Saulnier (Paris: Presses Universitaires de France, 1965). Following standard practice, the letter after the page number refers to the different layers of the text; $A=1580-1582$ edition; $B=1588$ edition; and $\mathrm{C}=$ additions made after 1588 and until Montaigne's death in 1592.

3. "It [De la Vanité] has a marked irregularity of form, and as familiarity with it increases, two outlines, two forms, may be distinguished in it. Presently two different dates are found in it as being each the date of its writing; and gradually it seems to shape itself as two different essays; to one of which belongs the title 'De la Vanite,' while that of the other might be 'Des Voyages."' Grace Norton, “The Essay called 'De la Vanite'”, Studies in Montaigne (New 
York: Macmillan, 1904), pp. 62-63. Basing her argument mainly on questions of style and tone, Norton delineates how these "two essays" might have been joined together.

4. MacPhail comes to much the same conclusion: "His essay will be a ceaseless journey of vanity and also of dissipation, for he could follow his subject until he used up all the paper and ink in the world." Eric MacPhail, The Voyage to Rome (Saratoga, CA: Anma Libri, 1990), p. 181.

5. Terence Cave, The Cornucopian Text (Oxford: Oxford University Press, 1979), p. 147.

6. Cf. "And I command enjoyment, for man has no good thing under the sun but to eat, and drink, and enjoy himself, for this will go with him in his toil through the days of life which God gives him under the sun" (8:15). See also, 2:24, 5:18-19, 9:7, and 11:8-10.

7. "Je ne sache point meilleure escolle, comme j'ai dit souvent" (973B, my emphasis).

8. "Je me tien à cheval sans demonter, tout choliqueux que je suis ..., Nulle saison $m$ 'est ennemye ..., Je voudroy sçavoir ..., $J$ 'ayme les pluies ..., La mutation ... ne me touche ..., Je ne suis battu . . ., Je suis mal-aisé . .., J'estrive . . ., J'ay apris . ., L'autre façon . . ., Mes chevaux ..., Jamais cheval ne $m$ ' a failli ..., Je les abreuve ..., La paresse à $m e$ lever ..., Pour moy je ne mange ..." (974BC). Only the sentence beginning with "L'autre façon" is not personalized.

9. "C'est une vieille question que savoir si un auteur peut parler de soi [. . . . Car parler de soi fait soup̧̧onner la vanité, vice que doivent éviter le rhéteur et l' auteur de bonne compagnie." Hugo Friedrich, Montaigne (Paris, Gallimard, 1969), p. 238. Friedrich cites Cicero's De Officiis, I, 137 as an example: "Deforme etiam est de se ipsum praedicare, falsa praesertim."

10. Montaigne makes much the same observation when he criticizes the "Roys de Perse" (973) for limiting themselves to drinking the water from just one river.

11. “. . j'estime tous les hommes mes compatriotes, et embrasse un Polonois comme un François, post-posant cette lyaison nationale à l'universelle et commune" (973B).

12. "Au rebours, je peregrine tressaoul de nos façons, non pour cercher des Gascons en Sicile (j'en ay assez laissé au logis); je cerche des Grecs plustost, et des Persans: j'acointe ceuxlà, je les considere; c'est là où je me preste et où je m'employe" (986B); and "Quand j'ay esté ailleurs qu'en France et que, pour me faire courtoisie, on m'a demandé si je vouloy estre servy à la Françoise, je m'en suis mocqué et me suis tousjours jetté aux tables les plus espesses d'estrangers" (985C).

13. "La diversité des façons d'une nation à autre ne me touche que par le plaisir de la variété. Chaque usage a sa raison" (985B).

14. "Je respons ordinairement à ceux qui me demandent raison de mes voyages: que je sçay bien ce que je fuis, mais non pas ce que je cerche" (972B).

15. Cf. also, "There is an evil which I have seen under the sun, and it lies heavy upon men: a man to whom God gives wealth, possessions, and honor, so that he lacks nothing of all that he desires, yet God does not give him power to enjoy them, but a stranger enjoys them; this is vanity; it is a sore affliction" (Eccl., 6:1-2). 